Dariusz Kużelewski

Uniwersytet w Biatymstoku

\title{
WYBORY ŁAWNIKÓW A ZASADA UDZIAŁU CZYNNIKA SPOŁECZNEGO W SPRAWOWANIU WYMIARU SPRAWIEDLIWOŚCI W SPRAWACH KARNYCH
}

\section{Wprowadzenie}

Udział czynnika społecznego w sprawowaniu wymiaru sprawiedliwości budzi w doktrynie rozbieżne oceny. Mimo prowadzonych w przeszłości badań nad rolą lawników w polskim procesie karnym, ich wpływie na podejmowanie decyzji procesowych, problematyka ta nie została jeszcze wyczerpana. Celem niniejszego artykułu jest przybliżenie roli ławników w procesie karnym w Polsce oraz ukazanie sposobu ich wyboru. Jednym z zagadnień traktowanych w sposób uboczny w literaturze przedmiotu jest kwestia wyboru na tę funkcję. W 2015 r. kończy się kolejna czteroletnia kadencja ławników w sądach powszechnych w Polsce. Rok ten jest więc jednocześnie rokiem wyborczym na kolejną kadencję na lata 2016-2019. Między innymi powyższy czynnik winien uzasadniać większe zainteresowanie w naszym kraju sędziami społecznymi, choć na pierwszy rzut oka są oni obecnie zjawiskiem marginalnym $\mathrm{w}$ polskich sądach, biorąc udział w rozpatrywaniu zaledwie niecałych $0,6 \%$ wszystkich spraw karnych sądzonych w I instancji. ${ }^{1}$ Rodzi się więc pytanie, czy jest to prawidłowe urzeczywistnienie zasady udziału czynnika społecznego w orzekaniu, a może wręcz świadczy to o nieistnieniu takiej zasady.

Ławnicy według doktryny realizują co najmniej trzy główne, odmienne, a jednocześnie uzupełniające się funkcje: działają jako czynnik kontroli społecznej (zabezpieczając czynnik zawodowy przed popadnięciem w rutynę oraz wywierając nań dyscyplinujący wpływ), są sędziami społecznymi sensu stricto (gwarantując kolegialność orzekania) oraz pełnią rolę łącznika wymiaru sprawiedliwości ze społeczeństwem. ${ }^{2}$ Kontrola społeczna polega nie tylko na obecności ławników w składzie

S. Waltoś, W dziesięciolecie obowiązywania kodeksu postępowania karnego, „Państwo i Prawo” 2009, z. 4, s. 6. Zob. D. Pożaroszczyk, Refleksje na temat instytucji ławników w polskim procesie karnym, (w:) B.T. Bieńkowska, D. Szafrański (red.), Problemy prawa polskiego i obcego w ujęciu historycznym, praktycznym i teoretycznym. Część czwarta, Warszawa 2013, s. 174-180 i powołana tam literatura. 
sądu oraz udziale we wszystkich czynnościach procesowych w trakcie rozprawy, ale również na możliwości aktywnego wpływu na przebieg postępowania i jego wynik, zapobiega rutynie sędziów zawodowych oraz dyscyplinuje ich do większej staranności i prawidłowości postępowania, wreszcie wzmacnia niezawisłość sędziowską, gdyż oddziaływanie na ławnika jest trudniejsze niż na sędziego zawodowego podlegającego ocenom, naciskowi opinii społecznej i mediów. Druga funkcja wyraża się w decydowaniu wspólnie z sędzią zawodowym o winie i karze. Trzecia zaś związana jest $\mathrm{z}$ faktem, iż ławnik wnosi do orzekania nie tylko własne doświadczenie życiowe oraz wiedzę, ale również opinię i poczucie sprawiedliwości środowiska, w którym się obraca. Z drugiej strony przekazuje do swojego środowiska zarówno własne opinie, oceny i doświadczenie związane z orzekaniem, jak też punkt widzenia i politykę karną ustawodawcy i przedstawicieli wymiaru sprawiedliwości. ${ }^{3}$

\section{Czynnik społeczny w procesie karnym}

Jednym z istotnych przejawów współczesnego nowoczesnego państwa demokratycznego jest dopuszczenie do udziału w sprawowaniu wymiaru sprawiedliwości nie tylko profesjonalistów, lecz również przedstawicieli społeczeństwa, czyli tzw. czynnika społecznego. Udział czynnika społecznego nie ogranicza się jednak tylko do ferowania orzeczeń. W procesie karnym, gdzie udział obywateli ma szczególne znaczenie ze względu na konieczność zapewnienia daleko posuniętej gwarancyjności dla stron (zwłaszcza dla oskarżonego) poprzez sprawowanie w pewnym sensie społecznej kontroli nad tokiem postępowania, zasada udziału czynnika społecznego może być rozumiana w ramach następujących zakresów przedmiotowych:

1) zasada udziału czynnika społecznego w ujęciu wąskim (sensu stricto), która określa bezpośredni udział obywateli w sprawowaniu wymiaru sprawiedliwości (w polskim procesie są to ławnicy),

2) zasada udziału czynnika społecznego sensu largo, która obejmuje oprócz wskazanego wyżej bezpośredniego udziału w wymiarze sprawiedliwości także formy udziału pośredniego, czyli współdziałanie w procesie karnym $w$ innych rolach, np. przedstawiciela społecznego czy poręczyciela społecznego,

3) zasada udziału czynnika społecznego w ujęciu najszerszym, która zawierając wymienione wyżej formy obejmuje także udział tego czynnika jako publiczności na rozprawie czy też uzupełniająco jako obywateli współdziałających w ściganiu karnym. ${ }^{4}$

F. Prusak, Czynnik społeczny w procesie karnym, Warszawa 1975, s. 27-29.

B. Janusz-Pohl, Zasada udziału czynnika społecznego, (w:) P. Wiliński (red.), System prawa karnego procesowego. Tom III Cz. 2. Zasady procesu karnego, Warszawa 2014, s. 1457. 
Mimo pojawiających się wątpliwości czy na gruncie Konstytucji RP z dnia 2 kwietnia 1997 r., ${ }^{5}$ której art. 182 w enigmatyczny sposób zapewnia udział obywateli w sprawowaniu wymiaru sprawiedliwości i jednocześnie odsyła do przepisów ustawy, w ogóle jest możliwe wyodrębnienie omawianej zasady, ${ }^{6}$ doktryna - często siłą tradycji - zdaje się aprobować jej istnienie. Wskazuje się, że w ujęciu dyrektywalnym zasada ta nakazuje organom procesu karnego, by dopuszczać do udziału w postępowaniu karnym obywateli (czynnik społeczny) zawsze wtedy, gdy przepis szczególny taką możliwość formułuje, zwłaszcza w sytuacji, gdy inicjatywa uczestnictwa w postępowaniu wypływa od samych obywateli. ${ }^{7}$

Bezpośredni udział obywateli w sprawowaniu wymiaru sprawiedliwości może wystąpić w jednym z trzech wariantów:

1) udziału ,totalnego", występującego w postaci sądów obywatelskich złożonych wyłącznie z podmiotów nieprofesjonalnych,

2) udziału w ramach składów mieszanych, tj. sędziów zawodowych i ławników,

3) udziału w formie ławy przysięgłych funkcjonujących w oparciu o zasadę podziału kompetencji pomiędzy sędziów społecznych (,sędziów faktu”) oraz sędziów zawodowych (,sędziów prawa”). ${ }^{8}$

Pierwszy model jest dość rzadko spotykany. Najbardziej znany przykład to angielski sędzia pokoju. W Polsce zaś organami złożonymi wyłącznie z nieprofesjonalistów były powołane w 1946 r. sądy obywatelskie oraz funkcjonujące w latach 1960-1990 sądy społeczne. ${ }^{9}$ Model drugi znany jest m.in. w Niemczech, Austrii, Belgii, Danii, Rosji, ${ }^{10}$ zaś ławy przysięgłych funkcjonują przede wszystkim w krajach anglosaskich (Wielka Brytania, USA), ale też we Francji. ${ }^{11}$

W polskim systemie prawnym utrwalił się system składów mieszanych zawodowo-ławniczych. Konstytucyjną zasadę udziału czynnika społecznego w sprawowaniu wymiaru sprawiedliwości uszczegółowia art. $4 \S 1$ i 2 ustawy z dnia 27 lipca 2001 r. Prawo o ustroju sądów powszechnych (p.u.s.p.), ${ }^{12}$ przewidując, że w sprawowaniu wymiaru sprawiedliwości obywatele biorą udział przez uczestnictwo ławników w rozpoznawaniu spraw przed sądami w pierwszej instancji, chyba że ustawy stanowią inaczej, a przy rozstrzyganiu spraw ławnicy mają równe prawa z sędziami. Z kolei art. 169 § 1 i 2 tejże ustawy gwarantuje, że w zakresie orzekania ławnicy są

\footnotetext{
$5 \quad$ Dz.U. z 1997 r. Nr 78, poz. 483 z późn. zm.

6 Zob. S. Waltoś, Ławnik - czy piąte koło u wozu?, (w:) T. Grzegorczyk (red.), Funkcje procesu karnego. Księga jubileuszowa Profesora Janusza Tylmana, Warszawa 2011, s. 524-526.

B. Janusz-Pohl, Zasada..., op. cit., s. 1451. Ibidem, s. 1438-1439.

Zob. M. Fajst, Udział czynnika społecznego w wymiarze sprawiedliwości, „Studia luridica” 1998, t. XXXV, s. $50-62$.

10 Zob. A.S. Bartnik, Sędzia czy kibic? Rola ławnika w wymiarze sprawiedliwości III RP. Analiza socjologiczno-prawna, Warszawa 2009, s. 26-27 i powołana tam literatura.

11 Zob. K. Wieczorek, Udział czynnika społecznego w orzekaniu w polskim i amerykańskim procesie karnym, Szczecin 2012, s. 16.

12 Tekst jedn. Dz.U. z 2013 r., poz. 427 z późn. zm.
} 
niezawiśli i podlegają tylko Konstytucji oraz ustawom. W odróżnieniu od sędziów zawodowych nie mogą jedynie przewodniczyć na rozprawie i naradzie ani też wykonywać czynności sędziego poza rozprawą, chyba że ustawy stanowią inaczej.

\section{Udział ławników w orzekaniu w sprawach karnych w Polsce}

Zakres udziału ławników w sprawach karnych reguluje Kodeks postępowania karnego z 6 czerwca 1997 r., ${ }^{13}$ który w art. 3 potwierdza zasadę udziału czynnika społecznego w wymiarze sprawiedliwości („,w granicach określonych w ustawie postępowanie karne odbywa się z udziałem czynnika społecznego"). Zakres ten obecnie jest znacznie zawężony niż miało to miejsce $\mathrm{w}$ chwili wejścia w życie k.p.k. Ustawa z dnia 15 marca 2007 r. o zmianie ustawy - Kodeks postępowania cywilnego, ustawy - Kodeks postępowania karnego oraz o zmianie niektórych innych ustaw ${ }^{14}$ przekreśliła dotychczasową zasadę kolegialności składu sędziowskiego i wprowadziła prymat jednoosobowego składu sądu w I instancji. Ławnicy orzekają tylko w sądzie okręgowym w sprawach o zbrodnie, czyli czyny zagrożone karą co najmniej 3 lat pozbawienia wolności, gdzie obowiązuje skład jednego sędziego i dwóch ławników (art. 28 § 2 k.p.k.), zaś w przypadku zbrodni zagrożonych karą dożywotniego pozbawienia wolności sąd proceduje w składzie dwóch sędziów i trzech ławników (art. 28 $\S 4$ k.p.k.).

Z dniem 1 lipca 2015 r. weszła w życie ustawa z dnia 27 września 2013 r. o zmianie ustawy - Kodeks postępowania karnego oraz niektórych innych ustaw, ${ }^{15}$ która w art. $28 \S 3$ k.p.k. wprowadziła możliwość rozszerzenia postanowieniem sądu składu orzekającego w pierwszej instancji nie tylko jak dotychczas do trzech sędziów, ale również do jednego sędziego i dwóch ławników. Warunkiem jest w tym przypadku wzgląd na szczególną zawiłość sprawy lub jej wagę. Zastanawiające jest, że ustawodawca nie ogranicza możliwości rozszerzenia składu o ławników tylko do sądu okręgowego, ale literalnie zezwala na to w pierwszej instancji, a więc również w sądzie rejonowym. Szkopuł w tym, że ławnicy w sprawach karnych zostali z sądów rejonowych wyrugowani wspomnianą nowelizacją z 2007 r. Czy zatem na najbliższą i kolejne kadencje trzeba będzie wybierać również ławników do sądów rejonowych, którzy być może w ogóle nie będą mieli ani razu szansy orzekania w procesie karnym, skoro skład ławniczy będzie tam zjawiskiem wyjątkowym i fakultatywnym? 


\section{Warunki wyboru na ławnika}

W polskim systemie wymiaru sprawiedliwości kadencja ławników trwa cztery lata kalendarzowe następujące po roku, w którym dokonano wyborów, zaś po upływie kadencji ławnik może brać udział jedynie w rozpoznawaniu sprawy rozpoczętej wcześniej z jego udziałem, do czasu jej zakończenia (art. 165 § 1 i 2 p.u.s.p.). Ławnikiem może zostać wybrana osoba, która na podstawie art. $158 \S 1$ p.u.s.p.:

1) posiada obywatelstwo polskie i korzysta $\mathrm{z}$ pełni praw cywilnych i obywatelskich,

2) jest nieskazitelnego charakteru,

3) ukończyła 30 lat,

4) jest zatrudniona, prowadzi działalność gospodarczą lub mieszka w miejscu kandydowania co najmniej od roku,

5) nie przekroczyła 70 lat,

6) jest zdolna, ze względu na stan zdrowia, do pełnienia obowiązków ławnika,

7) posiada co najmniej wykształcenie średnie.

Dodatkowo w przypadku orzekania w sprawach z zakresu prawa pracy ławnikiem może być osoba wykazująca szczególną znajomość spraw pracowniczych (art. $158 \S 3$ p.u.s.p.).

Funkcji ławnika nie mogą sprawować wobec wyraźnego zakazu w art. $159 \S 1$ p.u.s.p.

1) osoby zatrudnione $w$ sądach powszechnych i innych sądach oraz w prokuraturze,

2) osoby wchodzące w skład organów, od których orzeczenia można żądać skierowania sprawy na drogę postępowania sądowego,

3) funkcjonariusze Policji oraz inne osoby zajmujące stanowiska związane ze ściganiem przestępstw i wykroczeń,

4) adwokaci i aplikanci adwokaccy,

5) radcy prawni i aplikanci radcowscy,

6) duchowni,

7) żołnierze w czynnej służbie wojskowej,

8) funkcjonariusze Służby Więziennej,

9) radni gminy, powiatu i województwa.

Podobnie jak w przypadku ograniczania katalogu spraw, w których biorą udział ławnicy, w ostatnich latach zauważalna jest również tendencja do wprowadzania obostrzeń co do możliwości kandydowania na funkcję ławnika (np. cenzus wykształcenia co najmniej średniego, odpowiedni stan zdrowia, zakaz sprawowania tej funkcji przez radnego gminy, powiatu i województwa), jak również ściślejszego regulowania samego procesu wyborczego (np. wyraźne wyłączenie możliwości 
zgłaszania kandydatów na ławników przez partie polityczne, zwiększenie liczby obywateli zgłaszających kandydaturę z 25 do 50, określenie w ustawie jakie dokumenty muszą zostać dołączone do zgłoszenia kandydata na ławnika). ${ }^{16}$ Wprowadzone utrudnienia na drodze do uzyskania statusu lawnika oraz mniejsza liczba mandatów do obsadzenia z pewnością wyeliminowały wiele osób przypadkowych, patrzących na funkcję ławnika głównie przez pryzmat rekompensaty pieniężnej lub reprezentujących niski poziom intelektualny. Część osób mogła zostać zniechęcona perspektywą konieczności wydatku kwoty ok. 100 zł za zaświadczenie o niekaralności oraz zaświadczenie lekarskie przy braku gwarancji zostania wybranym przez radę gminy. $Z$ pewnością więc $w$ latach 2012-2015 motywacja i poziom merytoryczny ławników był zdecydowanie wyższy niż w poprzednich kadencjach. Zauważyć jednak należy, że koszt związany ze złożeniem dokumentów w trakcie naboru na ławników na kadencję 2016-2019 istotnie zmniejszył się, gdyż uzyskanie informacji o niekaralności wiąże się obecnie z opłatą w wysokości 30 zł (§ 3 ust. 1 rozporządzenia Ministra Sprawiedliwości z dnia 18 czerwca 2014 r. w sprawie opłat za wydanie informacji z Krajowego Rejestru Karnego ${ }^{17}$ ), zaś zaświadczenie lekarskie o braku przeciwwskazań do wykonywania funkcji ławnika można uzyskać nieodpłatnie u lekarza udzielającego świadczeń z zakresu podstawowej opieki zdrowotnej (np. specjalisty w dziedzinie medycyny rodzinnej).

\section{Postulaty modyfikacji systemu wyboru ławników}

Zauważyć należy, że obecny system wyłaniania ławników w Polsce jest dziedzictwem PRL-u. Jego zasady ukształtowane zostały w latach 50. i 60. XX wieku. ${ }^{18}$ $\mathrm{O}$ ile w pewien sposób zmianie uległ mechanizm nominowania kandydatów na ławników, których początkowo odgórnie wysuwały prezydia rad narodowych, następnie zebrania pracowników zakładów pracy, zebrania wiejskie oraz zebrania członków organizacji społecznych, obecnie zaś organizacje społeczne, grupy co najmniej 50 obywateli lub prezesi właściwych sądów, o tyle akt samego wyboru na funkcję ławnika w dalszym ciągu należy do lokalnego organu uchwałodawczego - rady gmin zastąpiły $\mathrm{w}$ tym aspekcie funkcjonujące $\mathrm{w}$ poprzednim ustroju rady narodowe. Utrzymany został również obowiązek powołania komisji - wcześniej wyznaczanej przez prezydium rady narodowej, a obecnie przez radę gminy - której zadaniem jest opiniowanie zgłoszonych kandydatów. Pozostały jednak te same problemy związane z niedookreślonością procedur oraz czynnikami pozamerytorycznymi na etapie opiniowania kandydatów przez komisję rady gminy. Badania praktycznych aspektów

\footnotetext{
16 Zmiany takie wprowadzone zostały ustawą z dnia 15 kwietnia 2011 r. o zmianie ustawy - Prawo o ustroju sądów powszechnych (Dz.U.z 2011 r. Nr 109, poz. 627).

17 Dz.U. z 2014 r., poz. 861.

18 Na temat ewolucji trybu wysuwania i wyborów ławników w tamtych czasach zob. M. Rybicki, Ławnicy ludowi w sądach PRL, Warszawa 1968, s. 220-235.
} 
wyboru ławników na kadencję 2004-2007 wykazały duże zróżnicowanie praktyk stosowanych w poszczególnych radach gmin, jak też w skrajnych przypadkach stosowanie kryterium sympatii politycznych czy osobistych decydentów wobec określonych kandydatów. ${ }^{19}$ Nawet obecnie, gdy partie polityczne formalnie wyłączone są z możliwości wysuwania kandydatów, nie ma przeszkód, aby przeforsować „swoich" w trakcie prac komisji nad opiniami, a następnie w trakcie ostatecznego głosowania przez radę gminy. Zbliżony jest także do obowiązującego w poprzednim systemie kalendarz wyborczy - wybory ławników w październiku roku poprzedzającego nową kadencję, złożenie ślubowania przez ławników najpóźniej w grudniu.

Zastrzeżenia wobec obowiązującego od lat systemu wyboru ławników powodują, że w literaturze wysuwa się i dyskutuje propozycje zmian. Wskazuje się na co najmniej cztery możliwe sposoby wyłaniania ławników:

- wybory powszechne ${ }^{20}$ - jak się wydaje jedynym plusem jest w tym przypadku pełny demokratyzm takiej procedury, natomiast do ujemnych stron zaliczyć należy potencjalnie niską frekwencję wśród głosujących, znaczne koszty zorganizowania powszechnego głosowania (nawet gdyby skorelować je z wyborami samorządowymi), obawę przed znacznym upolitycznieniem wyborów, a co za tym idzie samego wymiaru sprawiedliwości, ustąpienie walorów merytorycznych kandydatów przed socjotechniką wyborczą i chwytami populistycznymi; jak wskazują badania, są temu przeciwni również sędziowie ${ }^{21}$ i radni, ${ }^{22}$

- losowanie spośród członków społeczności lokalnej na podobieństwo procedury wyłaniania ławy przysięgłych w USA ${ }^{23}$ - niewątpliwą zaletą byłoby oderwanie od polityki (ławnicy wskazani dzięki przypadkowi), jednak wady i w tym przypadku przeważają (konieczność sądzenia przez osoby przypadkowe, niemające zupełnie na to ochoty i nieposiadające odpowiedniej wiedzy, inteligencji, doświadczenia życiowego, predyspozycji),

- wybór przez właściwe sądy ${ }^{24}$ - w przypadku kandydatów mających już wcześniejsze doświadczenie w wykonywaniu funkcji ławnika i pozytywnie ocenianych przez sędziów, z którymi orzekali, taka procedura z pewnością by się sprawdziła, jednak zanegowany zostałby przy tym właściwy wymiar czynnika społecznego, istniałaby obawa przed zdominowaniem

\footnotetext{
19 Zob. A.S. Bartnik, Sędzia czy kibic?..., op. cit., s. 44-54.

20 Zwolenniczką tego sposobu jest A.S. Bartnik, Sędzia czy kibic?..., op. cit., s. 199.

21 Zob. P. Sitniewski, Analiza wyników ankiet prezesów sądów w zakresie wyboru ławników, jakości ich pracy oraz funkcjonowania w ramach wymiaru sprawiedliwości, (w:) J. Ruszewski (red.), Ławnicy - społeczni sędziowie w teorii i praktyce. Ocena funkcjonowania i procesu wyboru ławników sądowych na przykładzie sądów Apelacji Białostockiej, Suwałki 2011, s. 94.

22 J. Ruszewski, Udział radnych w wyborze ławników oraz ocena ich udziału w sprawowaniu wymiaru sprawiedliwości w opiniach radnych, (w:) J. Ruszewski (red.), Ławnicy - społeczni sędziowie w teorii i praktyce..., op. cit., s. 158.

23 Szerzej na temat procedur związanych z ustalaniem składu ławy przysięgłych w USA zob. K. Wieczorek, Udział czynnika..., op. cit., s. 94-121.

24 Zob. D. Pożaroszczyk, Refleksje na temat..., op. cit., s. 182.
} 
i podporządkowaniem ławników interesom środowiska sędziowskiego, mogłoby dojść do utraty niejako kontrolnego wpływu na sędziów zawodowych i wymiar sprawiedliwości, zaś sami ławnicy nabraliby rytu technokratycznego - zresztą nawet obecnie mając możliwość wysuwania swoich kandydatów na ławników, prezesi sądów nie kwapią się do wykorzystywania tej prerogatywy,

- egzamin na ławnika ${ }^{25}$ - plusem tej koncepcji byłby jak się wydaje większy profesjonalizm, autorytet oraz akceptacja ławników przez społeczeństwo i przedstawicieli wymiaru sprawiedliwości, z drugiej jednak strony taki egzamin może odstręczać od kandydowania i przyciągać jedynie jednostki silnie zdeterminowane, ale niekoniecznie kompetentne i posiadające tzw. kompetencje miękkie - być może pomysł wart byłby rozważenia jako jeden z kilku elementów procesu wyboru na ławnika.

Każda z wyżej wskazanych alternatyw jest więc równie - jeśli nie bardziej - kontrowersyjna od obowiązującego systemu wyłaniania ławników w Polsce. Być może warto zastanowić się nad uzupełnieniem obecnego procesu wyborczego o możliwość wysuwania kandydatów na ławników spośród członków społeczności akademickiej oraz ewentualnie innych osób cieszących się szacunkiem społecznym przez senaty uczelni wyższych, co powinno również zwiększać autorytet i fachowość kandydatów, stanowić niejako gwarancję ich wysokiej jakości.

\section{Podsumowanie}

Podsumowując rozważania dotyczące udziału czynnika społecznego w sprawowaniu wymiaru sprawiedliwości w sprawach karnych w Polsce, zgodzić się należy z konstatacją, iż ławnicy w PRL - wbrew oczekiwaniom ówczesnych władz - stali się czynnikiem łagodzącym wymiar sprawiedliwości, choć autorytaryzm nie toleruje pełnej niezawisłości sędziów i ławników i jeśli nie znajduje innego rozwiązania, chętnie ograniczy lub zlikwiduje udział przedstawicieli społeczeństwa w wymiarze sprawiedliwości. ${ }^{26}$ Wydaje się, że i dziś ławnicy są solą w oku - tym razem technokratów ufających jedynie w całkowicie sprofesjonalizowany wymiar sprawiedliwości. 


\section{BIBLIOGRAFIA}

Bartnik A.S., Sędzia czy kibic? Rola ławnika w wymiarze sprawiedliwości III RP. Analiza socjologiczno-prawna, Warszawa 2009

Fajst M., Udział czynnika społecznego w wymiarze sprawiedliwości, Studia Iuridica 1998, t. XXXV

Janusz-Pohl B., Zasada udziału czynnika społecznego, (w:) P. Wiliński (red.), System prawa karnego procesowego. Tom III Cz. 2. Zasady procesu karnego, Warszawa 2014

Pożaroszczyk D., Refleksje na temat instytucji ławników w polskim procesie karnym, (w:) B.T. Bieńkowska, D. Szafrański (red.), Problemy prawa polskiego i obcego w ujęciu historycznym, praktycznym i teoretycznym. Część czwarta, Warszawa 2013

Prusak F., Czynnik społeczny w procesie karnym, Warszawa 1975

Ruszewski J., Udział radnych w wyborze ławników oraz ocena ich udziału w sprawowaniu wymiaru sprawiedliwości w opiniach radnych, (w:) J. Ruszewski (red.), Ławnicy - społeczni sędziowie w teorii i praktyce. Ocena funkcjonowania i procesu wyboru ławników sądowych na przykładzie sądów Apelacji Białostockiej, Suwałki 2011

Rybicki M., Ławnicy ludowi w sądach PRL, Warszawa 1968

Sitniewski P., Analiza wyników ankiet prezesów sądów w zakresie wyboru ławników, jakości ich pracy oraz funkcjonowania w ramach wymiaru sprawiedliwości, (w:) J. Ruszewski (red.), Ławnicy - społeczni sędziowie w teorii i praktyce. Ocena funkcjonowania i procesu wyboru ławników sądowych na przykładzie sądów Apelacji Białostockiej, Suwałki 2011

Waltoś S., W dziesięciolecie obowiązywania kodeksu postępowania karnego, Państwo i Prawo 2009, z. 4

Waltoś S., Ławnik - czy piąte koło u wozu?, (w:) T. Grzegorczyk (red.), Funkcje procesu karnego. Księga jubileuszowa Profesora Janusza Tylmana, Warszawa 2011

Wieczorek K., Udział czynnika społecznego w orzekaniu w polskim i amerykańskim procesie karnym, Szczecin 2012 


\section{THE ELECTION OF LAY JUDGES AND THE PRINCIPLE OF PARTICIPATION BY CITIZENRY IN THE ADMINISTRATION OF CRIMINAL JUSTICE}

Participation in the administration of justice not just by professionals but also by representatives of the citizenry, is one of the important manifestations of contemporary modern democratic states. In recent years one can notice not only a reduction in the catalogue of cases involving lay judges, but also a tendency to introduce restrictions on the right to stand as a lay judge (e.g. the requirement of at least secondary education, adequate health, non-exercise of this function by a councillor of a municipality, county or province) as well as to regulate the electoral process more precisely (e.g. explicit exclusion of political parties from proposing candidates for lay judge appointments, raising the amount of citizens filing candidacy from 25 to 50, defining the documents that must be attached to the application for a lay judge post).

The current system of selection of lay judges in Poland is a legacy of communism, its principles founded in the 50s and 60s of the twentieth-century. Objections to the current selection system provoke proposals for making amendments. At least four possible ways of selecting lay judges can be proposed: general elections, drawing from among members of the local community, selection by competent courts or the introduction of a lay judge examination.

Each of the abovementioned options presents advantages and disadvantages. Perhaps it is worth considering complementing the current electoral process with the ability to nominate candidates as lay judges from among members of the academic community, or possibly other persons enjoying the respect of society by the senates of universities, which should serve to increase the authority and competence of candidates insofar that in essence it constitutes a guarantee of their quality.

Keywords: lay judge, citizenry, election, criminal proceedings

Słowa kluczowe: ławnik, czynnik społeczny, wybory, postępowanie karne 